\title{
A Desaposentação no Ordenamento Jurídico Brasileiro
}

\author{
Bethsaida de Sá Barreto Diaz Gino ${ }^{1}$; Érika Samara Santana Faustino Silva ${ }^{2}$; \\ Társis da Costa Carneiro Pontes Dantas ${ }^{3}$.
}

Resumo: Desaposentar significa o direito que o segurado que continuou ou retornou a atividade remunerada tem de renunciar ao ato jurídico perfeito da aposentadoria visando à obtenção no futuro de um novo benefício mais vantajoso, pois permaneceu a verter contribuições para ao custeio do sistema securitário. Esse instituto tem sido alvo de uma grande polêmica doutrinária e jurisprudencial quanto a sua admissibilidade. Administrativamente, o INSS vem negando todos os pedidos, sob o pretexto de ausência de previsão legal. Os segurados, então, socorrem-se do Judiciário, que, no entanto, possui decisões bastante conflitantes sobre a questão. A presente pesquisa abordando o tema de forma ampla procurou demonstrar de modo cabal à viabilidade da tese da desaposentação no Ordenamento Jurídico brasileiro através da desconstituição dos principais argumentos contrários ao assunto, a saber, o ato jurídico perfeito, desequilíbrio atuarial do sistema, falta de previsão legal e o artigo $18, \S 2^{\circ}$ da Lei ${ }^{\circ} 8.213 / 1991$. Provando assim, a validade e a vigência desse instituto no nosso sistema jurídico, já que encontra fundamento na própria Constituição Federal de 1988, pois visa resguardar direito individual do segurado e até mesmo princípios maiores norteadores do Estado brasileiro como, por exemplo, a dignidade da pessoa humana.

Palavras-Chave: Desaposentação. Viabilidade. Constituição Federal.

\section{The come out of Retirement in the Brazilian Legal System}

\begin{abstract}
Re-retire means the right of the insured that continued or returned to paid work must renounce the perfect legal retirement in order to obtain in the future a new more advantageous benefit since remained pouring contributions to fund the security-system. This institute has been the subject of great doctrinal and jurisprudential controversy as its admissibility. Administratively, the INSS has denied all requests under the pretext of lack of legal provision. Insureds, then, rely upon the judiciary, which, however, has quite conflicting decisions about the matter. This paper addressing widely the subject sought to fully demonstrate the viability of re-retirement thesis in the Brazilian legal system through the deconstitution of the main arguments against the issue, namely, the perfect legal act, actuarial imbalance of the system, lack of legal provision and article 18, $\S 2$, of Law No. $8.213 / 1991$. Thus proving the validity and effectiveness of this institution in our legal system, as it finds fundament in the Federal Constitution of 1988, it aims to protect individual rights of the insured and even guiding major principles of the Brazilian state, for example, the dignity of the human person.
\end{abstract}

Keywords: Re-retirement. Viability. Federal Constitution.

\footnotetext{
${ }^{1}$ Advogada pela Universidade Regional do Cariri - URCA, Pós-graduada em Direito Previdenciário e Trabalhista pela Universidade Regional do Cariri - URCA, Pós-graduada em Direito Processual Civil pela Universidade Regional do Cariri - URCA, Advogada, Sócia Proprietária do Escritório: Dantas \& Gino Advocacia, Primeira Vice-Presidente da Comissão de Direito Imobiliário da Ordem dos advogados do Brasil, Subseccional Juazeiro do Norte, Ceará.

${ }^{2}$ Advogada pela Universidade Regional do Cariri (2011) e especialista em Direito Processual Civil. Atualmente é advogada na área cível e Técnica do Seguro Social do Instituto Nacional do Seguro Social. Encontra-se em processo de especialização em Direito Constitucional. Tem experiência na área de Direito, com ênfase em Direito Previdenciário.

${ }^{3}$ Advogado. pela Faculdade Paraíso do Ceará - FAP, Pós-graduando em Direito Trabalho e Previdenciário pela Faculdade Paraíso do Ceará FAP, Advogado, Sócio do Escritório de Advocacia: Dantas, Gino \& Advogados Associados
} 
Id on Line Revista Multidisciplinar e de Psicologia

Id on Line Revista Multidisciplinar e de Psicologia

\section{Introdução}

Atualmente no Brasil, por diversas razões, é comum ter aposentados voltando ao mercado de trabalho para complementação de sua renda, tornando-se segurados obrigatórios do Regime Geral de Previdência Social visto que tornam a verter contribuições de forma compulsória.

Ocorre que, a legislação previdenciária dispõe que embora sejam segurados obrigatórios não fazem jus a qualquer prestação da previdência em razão dessa nova atividade remunerada, a não ser salário-família e reabilitação profissional. (Art. 18, §2 da Lei 8.213/91).

O pecúlio, extinto em 1994, apresentava-se como solução para a questão, tendo em visto que consistia na devolução dos valores vertidos por esses segurados após a aposentadoria, uma vez que não teria acesso igualitário ao sistema. A extinção do pecúlio deu origem a grande celeuma prática, pois muitos desses aposentados começaram a procurar o INSS para fins de utilização dessas novas contribuições no aumento de seus benefícios. A Autarquia, previdenciária nega os pedidos de recálculo das aposentadorias com base na falta de regulamentação legal, dando origem a diversas ações judiciais. De outra, banda o Poder Judiciário vem emitindo decisões conflitantes acerca do tema.

Neste cenário, surge na doutrina e jurisprudência pátria a tese da desaposentação. Tema de grande destaque no direito previdenciário atual pode ser conceituado como a renúncia a aposentadoria pelos segurados que continuam ou retornam a atividade remunerada, com a intenção de no futuro alcançar um novo e melhor benefício mediante utilização das novas contribuições no seu cálculo.

O tema é cercado de bastante polêmica em nosso ordenamento jurídico, dividindo a doutrina e a jurisprudência. As discussões recaem principalmente sobre a viabilidade atuarial da desaposentação, ato jurídico perfeito, falta de previsão legal e o art. $18, \S 2^{\circ}$ da Lei 8.213/91.

Segundo dados expostos pela procuradoria do INSS na sessão que deu início ao julgamento do Recurso Extraordinário 381.367 no STF, o Brasil possui hoje 500 mil aposentados que retornaram ao labor e contribuem para a Previdência. Deste modo, a polêmica discussão doutrinária e jurisprudencial quanto à possibilidade de renúncia dessas aposentadorias visando à obtenção de benefício mais vantajoso justifica o tema aqui exposto, pois uma boa e adequada aposentadoria é essencial ao seu beneficiário sendo imprescindível a demonstração da validade e da vigência da tese da desaposentação no Brasil.

Diante do exposto, não se pode ignorar a situação de transtorno a que muitos segurados brasileiros estão submetidos, pois trabalham, e no final de suas vidas, quando mais precisam de uma boa aposentadoria tem o seu pedido de renúncia para obtenção de um benefício mais vantajoso negado. Admitir a tese da desaposentação é respeitar a própria dignidade da pessoa humana, princípio maior que fundamenta todo o nosso Estado Constitucional Democrático. 
Id on Line Revista Multidisciplinar e de Psicoloqia

Id on Line Revista Multidisciplinar e de Psicologia

\section{Objetivo e Metodologia}

O presente estudo teve por objetivo refletir o fenômeno da desaposentação no Regime Geral de Previdência Social e a polêmica quanto ao seu cabimento no nosso sistema jurídico. Assim como, analisar as principais justificativas que levam muitos aposentados a procurar a desaposentação, avaliar o posicionamento dos tribunais superiores brasileiros sobre o tema e demonstrar a validade da tese da desaposentação no ordenamento jurídico brasileiro, a partir da demonstração da inconsistência dos principais argumentos contrários ao tema, quais sejam, desequilíbrio financeiro e atuarial do sistema, falta de previsão legal, ato jurídico perfeito e a questão do art. 18, § $2^{\circ}$ da Lei $\mathrm{n}^{\circ}$ 8.213/91. Esta pesquisa se propôs a desconstruir os principais argumentos contrários a desaposentação provando a sua exequibilidade em nosso sistema.

Para tanto esta Pesquisa se desenvolveu através de estudo bibliográfico, tendo como principais fontes livros doutrinários, artigos científicos, jurisprudências, bem como a análise da legislação previdenciária e da Constituição Federal. Sempre que necessário foi utilizado o método dedutivo de abordagem e a exegese jurídica para se chegar as principais conclusões.

\section{Desaposentação}

A desaposentação pode ocorrer tanto no Regime Geral como no Regime Próprio de Previdência Social. Em ambos os casos visa à melhoria das condições financeiras do segurado através da utilização do seu novo tempo de contribuição para cálculo de um benefício melhor.

Bramante (2001, p.150/151) sobre o conceito de desaposentação ensina que "é o desfazimento do ato administrativo concessivo do benefício previdenciário no regime de origem, de modo a tornar possível a contagem do tempo de serviço prestado em outro regime". Ou seja, também é possível que a desaposentação ocorra em um regime visando à obtenção de benefício melhor em outro regime, como acontece, por exemplo, nos casos em a aposentadoria ocorre no RGPS, com vínculo posterior em RPPS, caso em que mais tarde terá direito a aposentar-se pelo Regime Próprio.

Assim, há duas formas de desaposentação. A primeira ocorre quando um segurado se aposenta no RGPS ou em RPPS e permanece trabalhando, neste caso continua vinculado ao mesmo regime previdenciário e consequentemente vertendo suas contribuições. Ao parar definitivamente de trabalhar poderia anexar esse novo tempo de contribuição na aposentadoria para alcançar um benefício maior.

A segunda situação se apresenta quando um segurado aposenta-se em um regime e passa em concurso público em outro regime, caso em que lhe seria benéfico averbar o tempo de contribuição do regime antigo no novo, o que não é permitido, pois já possui benefício no regime de origem. A 
Id on Line Revista Multidisciplinar e de Psicologia

Id on Line Revista Multidisciplinar e de Psicologia

desaposentação, neste caso, excluiria o vínculo com o primeiro regime permitindo a averbação do tempo de contribuição no novo regime, permitindo com isso um benefício melhor para o segurado.

\section{Justificativas para a Desaposentação}

Em muitos casos a aposentadoria do segurado tende a ser menor que a sua remuneração decorrente da atividade laborativa, isso leva muitos aposentados a voltarem ao mercado de trabalho com o objetivo de complementar sua renda, o que é essencial para sua própria sobrevivência e de familiares.

Um dos fatores que causam a diminuição do benefício ao longo dos anos é a defasagem nas aposentadorias do RGPS que ocorre em razão da inflação e de alterações na moeda. A renda mensal do benefício sofre depreciação no reajustamento, pois os índices de atualização dos mesmos não alcançam a inflação real. Estes cenários levam muitos aposentados a voltarem ao mercado de trabalho com o objetivo de complementar sua renda, o que é essencial para sua própria sobrevivência e de familiares.

A Constituição Federal de 1988 nos assegura em seu artigo 194, Parágrafo Único, inciso IV, a irredutibilidade do valor dos benefícios, o que significa que os mesmos serão reajustados de acordo com a inflação visando à manutenção do seu poder de compra. Isso ocorre através do índice do INPC que é atualizado anualmente na mesma data do salário-mínimo. Apesar dessa previsão constitucional acaba ocorrendo à defasagem salarial.

Essa defasagem não ocorre como muitos pensam pela redução das aposentadorias, mas sim porque há uma perda inflacionária se compararmos o aumento dos benefícios previdenciários com o salário mínimo. É verdade que existe a possibilidade de revisão dos benefícios em algumas situações, aumentando o seu valor, mas isso não consegue solucionar o problema da defasagem. Ainda não temos nenhum dispositivo legal que possa corrigir essa situação o que leva muitos aposentados a procurarem uma nova ocupação para garantir que seus rendimentos serão similares quando da ativa.

Ademais, não existe equivalência que relacione custeio e benefício. Deste modo, por exemplo, um segurado que contribuiu durante todo o tempo que trabalhou sobre uma base de cálculo equivalente a dez salários mínimos não possui nenhuma garantia de que a sua aposentadoria equivalerá no futuro aos mesmos dez salários mínimos, principalmente após a criação do fator previdenciário que leva em consideração algumas variáveis. VIANA (2011, p. 477).

Ademais, outro motivo que leva o aposentado a procurar nova ocupação para a manutenção do padrão de vida que tinha antes de estar na condição de inativo é o fator previdenciário obrigatório nas aposentadorias por tempo de contribuição e não raras vezes leva a diminuição das mesmas, pois utiliza variáveis, como, idade, expectativa de sobrevida e tempo de contribuição. 
Id on Line Revista Multidisciplinar e de Psicoloqia

Id on Line Revista Multidisciplinar e de Psicologia

Além de tudo isso, o nosso ordenamento jurídico encontra-se subordinado a $\mathrm{CF} / 88$ que garante a liberdade de trabalho, ou seja, os cidadãos são livres para continuar trabalhando mesmo após a aposentadoria e também para se desfazer desse ato (Martinez, 2010, p. 960).

A nossa lei maior eleva o primado do trabalho a condição de um direito social fundamental, pois lhe confere proteção em diversos dispositivos promovendo a própria dignidade da pessoa humana. Desta forma, todos têm direito a escolher trabalhar, ou não, mediante remuneração justa, independentemente da aposentação. (Novelino, 2012, p.13).

Deste modo, claramente o direito ao trabalho se mostra como outra justificativa para a desaposentação. Encontrando-se constitucionalmente assegurado nos seguintes dispositivos: título VIII que disciplina a Ordem Social tendo como base o primado do trabalho; artigo $1^{\circ}$, inciso IV, sendo um os fundamentos da República Federativa do Brasil; artigo $6^{\circ}$, caput, como um direito social; e artigo $5^{\circ}$, inciso XIII, que dispõe ser "livre o exercício de qualquer trabalho, ofício ou profissão, atendidas as qualificações profissionais que a lei estabelecer".

Tendo sido o direito ao trabalho erigido a patamar constitucional chegamos à conclusão de que é um direito fundamental inviolável e que, portanto, o trabalhador tem direito a gozar todos os benefícios decorrentes do mesmo. Não sendo admissível, por conseguinte que o nosso ordenamento jurídico retire do aposentado que voltou ao labor o direito a uma melhor aposentadoria no futuro, posto que continua a verter contribuições para o custeio do sistema previdenciário como qualquer outro segurado. Ademais, tentar impedir a desaposentação pode gerar um desestímulo ao trabalho, o que constitui clara violação ao ordenamento constitucional.

Por fim, Salvador e Agostinho (2011, p. 29) discorrendo sobre desaposentação assim prelecionam:

Com efeito, inviável dissociar a desaposentadoria do contexto da proteção previdenciária, já que, integrante deste planejamento constitucional hipotético, no qual se apresenta como utilitário real e disponível dos trabalhadores aposentados, que visam uma melhor, justa e adequada aposentadoria, razão de que a pretensão pela desaposentação encontra total guarida na tutela estatal previdenciária, tal qual, aliás, é compreendida pelas suas Teorias Gerais.

Esses autores consideram o instituto da desaposentação como um modo de efetivar uma verdadeira proteção previdenciária, pois vai ao encontro da necessidade social do segurado assegurando-lhe uma melhor e mais justa aposentadoria.

Assim, permitir a desaposentação e a consequente utilização do seu novo tempo de contribuição para alcançar um benefício melhor e mais adequado no futuro são uma forma de obediência a nossa lei maior e também um instrumento para alcançar a justiça social. 
Id on Line Revista Multidisciplinar e de Psicoloqia

Id on Line Revista Multidisciplinar e de Psicologia

\section{Divergências Doutrinárias}

\section{A Questão do Art. 18, $§ 2^{\circ}$ da Lei 8.213/91}

Todos que exercem atividade remunerada em conformidade com o artigo 11 da lei $\mathrm{n}^{\circ}$ 8.213/91 são segurados obrigatórios da previdência social sendo obrigados a verter contribuições para o custeio do sistema, inclusive o segurado aposentado que continua trabalhando ou que voltou ao trabalho. A justificativa está no princípio da obrigatoriedade que norteia o sistema contributivo previdenciário.

Acontece que, o princípio da contraprestação determina que se o segurado contribuiu consequentemente tem direito a uma prestação previdenciária, pois a natureza jurídica dessas contribuições previdenciárias é de tributo e estes estão vinculados a uma prestação do Estado. Mas tal não ocorre com o segurado aposentado que continua ou retornou ao labor, pois segundo o $\S 2^{\circ}$ do artigo 18 da Lei n ${ }^{\circ}$ 8.213/91 não possui direito a prestações previdenciárias, exceto ao salário-família e a reabilitação profissional. Ou seja, tem obrigação de contribuir mais não se beneficia disso, pois estes dois únicos benefícios que a lei lhe confere muito dificilmente serão por eles utilizados, tendo em vista que o salário-família tem como requisitos que o segurado seja de baixa renda e que possua filhos menores de quatorze anos, segurados aposentados geralmente não possuem filhos pequenos, e a reabilitação profissional objetiva a reeducação ou readaptação do segurado incapacitado para o trabalho por motivo de doença ou acidente objetivando o seu retorno ao mercado de trabalho, esta situação é peculiar e também não muito comum.

Assim, diante desta norma os segurados aposentados que retornam ao labor encontram-se prejudicados não fazendo jus a contraprestações da previdência por suas contribuições obrigatoriamente vertidas.

Como solução para esta problemática tínhamos o instituto do pecúlio previsto nos arts. 81 e 82 da Lei $n^{\circ}$ 8.213/91, que consistia na devolução das contribuições previdenciárias, em uma única parcela, do período em que o aposentado voltou a contribuir até a sua saída definitiva do RGPS, mas que foi extinto pelo art. 29 da Lei ${ }^{\circ}$ 8.870/94. O pecúlio era devido ao segurado aposentado por idade, especial e por tempo de serviço que voltasse a atividade.

Com o fim do pecúlio surgiu grande discussão no meio previdenciário sobre as contribuições vertidas pelos segurados aposentados que voltam ao trabalho ou nele permanecem, principalmente após a criação do $\S 2^{\circ}$ do art. 18 da lei $8.213 / 91$. Tentando justificar a revogação do pecúlio foi incluído o $\S^{\circ}$ no artigo 11 da lei n $8.213 / 91$ que dispõe:

O aposentado pelo Regime Geral de Previdência Social-RGPS que estiver exercendo ou que voltar a exercer atividade abrangida por este Regime é segurado obrigatório em relação a essa atividade, ficando sujeito às contribuições de que trata a Lei ${ }^{\circ} 8.212$, de 24 de julho de 1991, para fins de custeio da Seguridade Social. 
Da leitura deste dispositivo claramente se percebe a intenção do legislador de livrar-se da responsabilidade pela contraprestação decorrente da contribuição previdenciária, justificando isto no princípio da solidariedade que determina que o sistema previdenciário deva ser custeado por todos, inclusive por aqueles que nunca venham a receber um benefício. Ou seja, o legislador pretende que o administrado contribua para o custeio do sistema sem, no entanto ter direito a desfrutar desses valores em seu benefício.

Acontece que vários doutrinadores e aplicadores do direito não concordam com o fato de o segurado contribuir e não usufruir, o que gera grandes discussões na doutrina e jurisprudência. Sobre essa questão as escritoras Ladenthin e Masotti prelecionam que se n]ao é possível devolver as contribuições então devem ser aproveitadas, respeitando-se assim princípios como o da contrapartida e dignidade da pessoa humana. (2012, p. 77) assim dispõem:

Outra questão levantada pelos doutrinadores que confere força a posição de que quem contribui tem direito a usufruir é o art. $201, \S 11$ da $\mathrm{CF} / 88$, in verbis: "Os ganhos habituais do empregado, a qualquer título, serão incorporados ao salário para efeito de contribuição previdenciária e consequente repercussão em benefícios, nos caso e na forma da lei."

Ou seja, esse artigo da nossa Carta Magna garante a repercussão em benefícios das contribuições previdenciárias. Para alguns estudiosos do direito ao determinar que o segurado aposentado não possua direito a prestações previdenciárias, exceto o salário-família e a reabilitação profissional o $\S 2^{\circ}$ do artigo 18 da lei $n^{\circ} 8.213 / 91$ estaria em confronto com a CF/88.

Foi nesse contexto de fim do pecúlio e consequente perda do direito aos valores pagos após a concessão da aposentadoria que surgiu em nosso cenário jurídico a tese da Desaposentação, pois se apresenta como a solução mais adequada para os inúmeros casos de segurados obrigatórios que retornaram ao labor, o que tem gerado inúmeras ações judiciais com esse fim, além de muita polêmica doutrinária e jurisprudencial sobre a sua admissibilidade ou não.

Entendemos que dentro desta problemática exposta o principal óbice à desaposentação é o $\S 2^{\circ}$ do artigo 18 da Lei n ${ }^{\circ}$ 8.213/91 que claramente confronta com o art. 201, $§ 11$ da CF/88. Conflito este que não se sustenta no nosso Ordenamento Jurídico, tendo em vista que a nossa Constituição Federal é rígida, dotada de supremacia e encontra-se no vértice na pirâmide normativa obrigando e vinculando todas as demais normas. Assim, todas as leis e atos normativos inferiores devem respeito à Constituição e, em caso de violação devem ser expurgadas do sistema jurídico por meio do controle de constitucionalidade. O professor e Advogado Lindoso (2013, p.1) também comunga dessa ideia ao dispor que:

Nesse contexto, o artigo $18, \S 2^{\circ}$, da Lei $\mathrm{n}^{\circ} 8.213 / 91$ incide em exuberante eiva de inconstitucionalidade, porquanto impede que as contribuições efetivadas pelo aposentado que permanece ou retorna à atividade repercutam no cálculo da 
respectiva aposentadoria, em descompasso com a diretriz expressamente traçada pela Lei Maior. Trata-se, assim, de verdadeiro processo de erosão do núcleo essencial previsto no artigo 201, §11, da Lei Magna, que deve ser repelido, pois não se pode conferir ao legislador ordinário o poder de atuar de forma a abolir direito fundamental, por se tratar de conduta vedada até mesmo ao Poder Constituinte Reformador (CF, art.60, $\S 4^{\circ}$, inciso IV).

Assim, concordamos com a doutrina que alega a inconstitucionalidade do $\S 2^{\circ}$ do art.18 da Lei $\mathrm{n}^{\circ}$ 8.213/91, por ferir a Constituição Federal. Aliás, tese esta defendida no Recurso Extraordinário 381.367, cujo julgamento já foi iniciado no STF.

\section{O Ato Jurídico Perfeito e a possibilidade de Renúncia da Aposentadoria}

Trata-se de um do mais controvertidos argumentos que vem dividindo a doutrina e a jurisprudência pátria, saber se o segurado pode renunciar a aposentadoria objetivando no futuro alcançar benefício mais vantajoso, tendo em vista a garantia constitucional do ato jurídico perfeito.

Dispõe o inciso XXXVI, art. $5^{\circ}$ da $\mathrm{CF} / 88$ : “A lei não prejudicará o direito adquirido, o ato jurídico perfeito, e a coisa julgada". Estando no capítulo que trata dos direitos e deveres individuais e coletivos, o ato jurídico perfeito foi erigido à cláusula pétrea (art.60, $\S 4^{\circ}, \mathrm{IV}, \mathrm{CF} / 88$ ), não podendo ser modificado nem mesmo por Emenda Constitucional.

A Concessão da aposentadoria pela autarquia previdenciária (INSS) tem natureza de um ato jurídico perfeito, é um direito adquirido do segurado, desta forma só pode ser desfeito pela própria administração em caso de fraude ou erro em sua concessão, mas jamais em prejuízo do beneficiário. Discorrendo sobre o ato concessório de aposentadoria Bandeira de Mello preleciona: "O ato administrativo é perfeito quando esgotadas as fases necessárias à sua produção. Portanto o ato perfeito é o que completou o ciclo necessário à sua formação. Perfeição, pois, é a situação do ato cujo processo está concluído." (2012, p. 272).

Assim sendo, vários doutrinadores brasileiros entendem que a aposentadoria concedida ao segurado pelo Regime Geral de Previdência Social não poderia ser por ele renunciada, pois isto violaria o ato jurídico perfeito e a própria garantia da segurança jurídica implicitamente insculpida no art. $5^{\circ}$, inciso XXXVI da CF.

Ocorre que, o propósito do ato concessório da aposentadoria ser um ato jurídico perfeito é justamente assegurar ao beneficiário a sua manutenção ao longo dos anos, garantindo-se assim segurança jurídica a quem já cumpriu todos os requisitos previstos em lei para adquirir este benefício. Assim, estamos de acordo com muitos estudiosos do direito quando afirmam não ser possível invocar garantias constitucionais, como o ato jurídico perfeito, para tentar impedir o exercício de algum direito pelo cidadão, pois estas têm por objetivo assegurar que os direitos não sejam violados e não limitar o 
Id on Line Revista Multidisciplinar e de Psicoloqia

Id on Line Revista Multidisciplinar e de Psicologia

gozo dos mesmos. Isto constituiria violação a própria Constituição. Neste sentido Ibrahim (2011, p. 49):

\begin{abstract}
Segurança jurídica, de modo algum, significa a imutabilidade das relações sobre as quais há a incidência da norma jurídica, mas sim, a garantia da preservação do direito, o qual pode ser objeto de renúncia por parte de seu titular em prol de situação mais benéfica.
\end{abstract}

Deste modo, em determinadas situações como no caso do direito a desaposentação, não se pode utilizar o dispositivo constitucional que prevê o ato jurídico perfeito para perenizar injustiças, pois o mesmo foi desenvolvido pelo legislador constituinte objetivando justamente o contrário, ou seja, a defesa do cidadão contra a ingerência do Estado. Assim, deve o aplicador do direito procurar coadunar este artigo constitucional com princípios basilares do nosso Ordenamento Jurídico Constitucional, sempre em prol da defesa dos interesses do cidadão que neste caso é o segurado. Tentar impedir a desaposentação utilizando uma garantia do povo contra ele mesmo é lesar a própria Constituição Federal.

Não é demais lembrar que vem sendo admitido por parte de nossos Tribunais e doutrinadores que a coisa julgada outra garantia prevista no art. $5^{\circ}$, inciso XXXVI da CF seja relativizada quando em confronto com valores maiores do sistema jurídico. Ou seja, as garantias do ato jurídico perfeito, do direito adquirido e da coisa julgada, não podem ser tidas com valores absolutos podendo ser desconstituídas, em situações excepcionais, quando confrontem com interesses dos administrados, pois estas visam à pacificação social, e não a restrição de direitos em detrimento da coletividade.

Ao estudar a Constituição não se pode pretender apenas analisar a aplicação literal de suas regras, mas deve-se fazer uma análise teleológica de seus dispositivos, pois é a hermenêutica jurídica que nos conduzirá ao caminho correto de interpretação em favor daqueles para quem a norma jurídica foi desenvolvida.

Em tempos modernos onde se discute cada vez mais a inclusão previdenciária, o Poder Público deve se esforçar ao máximo para reconhecer garantias dos seus segurados, pois em razão delas é que o sistema securitário foi desenvolvido. Neste contexto, a renúncia à aposentadoria pelo segurado visando a um benefício melhor no futuro é plenamente possível no sistema jurídico brasileiro, merecendo imediata discussão, aceitação e implementação, visto que configura uma prerrogativa essencial para os segurados. 
Id on Line Revista Multidisciplinar e de Psicoloqia

Id on Line Revista Multidisciplinar e de Psicologia

\title{
Viabilidade Atuarial da Desaposentação
}

Alguns doutrinadores brasileiros se posicionam contra a desaposentação sob o argumento de que ocorreria um desequilíbrio financeiro e atuarial com a sua concessão, se esta não estiver condicionada a devolução dos valores recebidos pelos segurados quando da primeira aposentadoria. Assim, denota-se que a problemática está na discussão sobre a necessidade de devolução dos valores recebidos pelos segurados. Trata-se de questão bastante polêmica na doutrina e também na jurisprudência.

Discorrendo sobre o assunto Ibrahim se posiciona no sentido da viabilidade atuarial da desaposentação (2008, p. 54):

\begin{abstract}
Do ponto de vista atuarial a Desaposentação seria plenamente justificável, pois se o segurado já goza de benefício, jubilado dentro das regras vigentes, atuarialmente definidas, presume-se que neste momento o sistema previdenciário somente fará desembolsos frente a este beneficiário, sem o recebimento de qualquer cotização, esta feita durante o período passado.
\end{abstract}

Neste sentido também prelecionam Landenthin e Masotti (2012, p. 88) ao afirmarem que se os segurados continuaram a atividade laboral e consequentemente a contribuir compulsoriamente, verteram contribuições que não eram esperadas ao sistema, tendo, portanto direito à desaposentação, sem a necessidade de devolução de valor algum.

De modo contrário, Martinez (2008, p. 111) "defende que deve haver a restituição do status quo ante, observados os parâmetros atuariais imprescindíveis".

Neste sentido também é a posição de Duarte (2003, p. 2) ao afirmar que com a desaposentação e sem a devolução de valores, a autarquia seria onerada duas vezes e que o mais justo é conceder efeito ex tunc à desaposentação e fazer retornar o status quo ante, devendo o segurado devolver o que recebeu do órgão gestor durante todo o tempo em que esteve aposentado.

Ao analisar os posicionamentos doutrinários acima mencionados percebemos que a doutrina não consegue chegar a um consenso sobre este polêmico tema. As posições jurisprudenciais também tem se mostrado bastante conflitantes entre si, conforme demonstraremos no capítulo seguinte.

Entendemos que a melhor doutrina neste caso é a que afirma não ocorrer desequilíbrio atuarial algum com a desaposentação, não havendo, portanto, necessidade de devolução de valores quando da sua concessão. Isso porque quando o segurado continua trabalhando depois de aposentado permanece a verter contribuições não esperadas, ou seja, nas palavras de Ladenthin e Masotti (2012, p.250) tais contribuições são um "plus" para o sistema, um adicional, uma quantia não esperada. Não sendo correto afirmar que oneram o sistema, pelo contrário geram receita não esperada, sendo estes os segurados que mais contribuem para a previdência, não fazendo jus a qualquer retorno em seu 
Id on Line Revista Multidisciplinar e de Psicologia

Id on Line Revista Multidisciplinar e de Psicologia

benefício, a não ser que possam desaposentar e ter suas aposentadorias recalculadas com base nessas novas cotizações vertidas, o que é justo e ideal.

Importante mencionar que em caso de ingresso do segurado no RPPS, o RGPS deixará de efetuar o pagamento do benefício ao segurado, remetendo os fundos acumulados ao RPPS, mediante compensação financeira. Não havendo que se falar em desequilíbrio atuarial no RGPS, visto que ainda que o beneficiário tenha recebido algumas parcelas da aposentadoria, os valores acumulados serão usados em período menor, já que com o tempo a expectativa de vida diminui. Não cabendo falar também nesta hipótese em restituição de valores pelo segurado.

Outro ponto que merece destaque é o caráter alimentar que possuem tais benefícios, pois visam substituir a remuneração do trabalhador não fazendo sentido falar, portanto, em devolução de valores, conforme lições de Tavares (2005, p. 247).

Destaca ainda esse autor que a aposentadoria é um direito patrimonial disponível que possibilitará ao seu titular procurar melhores condições econômicas podendo então, ser renunciada pelo seu titular.

Concluímos assim, que a desaposentação é plenamente cabível do ponto de vista atuarial e, sendo a aposentadoria verba alimentar, impossível falar em restituição de valores com a sua concessão.

\section{Posição do INSS}

O Instituto Nacional do Seguro Social (INSS) é a autarquia federal vinculada ao Ministério da Previdência Social responsável pela concessão e manutenção dos benefícios e serviços previdenciários do Regime Geral de Previdência Social.

Um dos fundamentos no qual se baseia o INSS para negar a desaposentação é o artigo $18, \S 2^{\circ}$ da Lei $\mathrm{n}^{\circ}$ 8.213/91 que dispõe expressamente que o aposentado pelo RGPS que continuar em serviço ou retornar não fará jus à prestação alguma da previdência social em decorrência dessa nova atividade, exceto salário-família e reabilitação profissional. Dispositivo legal já discutido em tópico próprio onde defendemos a sua inconstitucionalidade.

Outro argumento usado pela autarquia é o art. 181-B do Decreto $\mathrm{n}^{\circ} 3.048 / 99$, que determina que as aposentadorias por tempo de contribuição, especial e por idade são irreversíveis e irrenunciáveis. Ocorre que o decreto tem como única função regular a lei, não podendo o Executivo inovar. Com isso não pode este decreto dispor sobre a impossibilidade de renúncia ou reversão de benefícios previdenciários se a própria lei não o fez (LADENTHIN, MASOTTI, 2012, p. 156).

Além do mais, a autarquia no RE 661.256 está contestando no STF a decisão do STJ que concede o direito ao segurado de renúncia à aposentadoria para a obtenção de um benefício mais 
vantajoso sem, contudo haver a necessidade de devolução dos valores percebidos pelos segurados. Alega que a possibilidade de desaposentar sem devolução de valores vai de encontro ao princípio do equilíbrio atuarial e financeiro que tem previsão legal no artigo 195, caput, e parágrafo $5^{\circ}$ e 201, caput, da $\mathrm{CF} / 88$. Além do mais alega violação ao $5^{\circ}$, caput e inciso XXXVI, que determinam que a lei não prejudicará $\mathrm{o}$ ato jurídico perfeito.

Todavia, sem sombra de dúvida, o principal argumento utilizado pelo INSS para negar a tese da desaposentação é a falta de regulamentação legal do instituto.

Entende a administração pública que o desfazimento da aposentadoria somente seria admissível com previsão expressa de lei, conforme ocorre em alguns regimes próprios de previdência, inclusive no âmbito federal (Lei n⿳8.112/90, art. 25, II). Contudo, não assiste razão a esse pensamento, pois o mecanismo previsto no Estatuto dos servidores Federais não é a desaposentação construída pela doutrina e pela jurisprudência e sim, mera reversão do benefício, possibilitando ao servidor o retorno ao exercício da função pública (IBRAHIM, 2011, p. 68).

Ademais, concordamos com doutrina que sustenta que o Poder Público, neste caso, não faz uso da forma correta da amplitude do princípio da legalidade, que significa que a Administração Pública somente pode fazer o que a lei autorizar, ao contrário do administrado para o qual tudo é possível, desde que não vedado pela lei. Ou seja, a administração somente pode impor ao segurado as restrições previstas em lei. Neste sentido Coelho (2000, p. 2):

\begin{abstract}
Não bastasse, invocar o princípio da legalidade para deixar de reconhecer um direito público individual [à desaposentação] é relegar a um segundo plano os interesses do administrado; é elevar o referido princípio a um patamar que não ostenta o de sobrepor os direitos e garantias fundamentais outorgados pelo soberano Poder Constituinte de 1988 ao cidadão brasileiro, como, exempli gratia, o de que "ninguém será obrigado a fazer ou deixar de fazer alguma coisa senão em virtude de lei", inscrito no inciso II do art. $5^{\circ}$ da Lei Maior da Federação Brasileira. Nesse passo, inexistindo no nosso ordenamento jurídico vigente lei que proíba o desfazimento de aposentadoria regularmente deferida, impossível cogitar de indeferimento por conveniência e oportunidade da administração ou mesmo em razão de ausência de autorização legal, pois a renúncia de um direito que integrou o patrimônio de seu titular não clama por ilógicos e injurídicos pressupostos.
\end{abstract}

O que claramente se percebe é um confronto entre a Administração Pública e seus administrados no que tange a utilização do Princípio da Legalidade. Podemos vislumbrar a colisão entre dois princípios constitucionais, a saber, o Princípio da Liberdade e o Princípio da Supremacia do Interesse Público.

Assim, faz-se necessário ponderar os interesses para chegar à conclusão sobre qual dos dois princípios constitucionais deverá prevalecer na análise do caso concreto. Nestes casos entendemos que deverá prevalecer o Princípio da Liberdade do administrado, pois segundo Gisele Kravchychyn (2007, p. 2): 
A liberdade concedida e garantida constitucionalmente de que ninguém será obrigado a fazer ou deixar de fazer algo senão em virtude de lei é mais consistente do que o dever da administração de somente fazer aquilo que a lei permite ou determina.

Deste modo, deve prevalecer a possibilidade de renúncia à aposentadoria pelo segurado, pois sem dúvida os princípios e garantias individuais do cidadão insculpidos na Constituição Federal são mais importantes do que a Supremacia do Interesse Público.

Assim, como a desaposentação não está proibida em lei, presume-se que é permitida, desde que não haja violação a preceitos da nossa $\mathrm{CF} / 88$, pois não se pode utilizar o princípio da legalidade para colocar os interesses do cidadão em segundo plano e nem evocá-lo para negar-lhe o direito público individual à desaposentação.

Portanto, podemos perceber que apesar da existência de grande crítica doutrinária a posição da autarquia previdenciária é consolidada no sentido de não admitir a tese da desaposentação no Regime Geral de Previdência Social do Brasil. Ou seja, administrativamente não se concede a desaposentação. Com isso essa questão vem sendo resolvida apenas no Judiciário que, no entanto, apresenta soluções divergentes e conflitantes.

\section{Posicionamento do STJ}

Os Tribunais Regionais Federais possuem decisões divergentes e conflitantes sobre a admissibilidade ou não da desaposentação. Diante da controvérsia muitos recursos chegaram ao STJ (Superior Tribunal de Justiça), que é responsável pela uniformização da interpretação da Lei Federal em todo o território nacional. O Egrégio Tribunal, então, consolidou posicionamento favorável à desaposentação. Seu primeiro julgado neste sentido foi o REsp.692.628/DF, decidindo que:

$\mathrm{O}$ ato de renunciar a aposentadoria tem efeito 'ex nunc' e não gera o dever de devolver valores, pois, enquanto perdurou a aposentadoria pelo regime geral, os pagamentos, de natureza alimentar, eram indiscutivelmente devidos. Ladenthin e Masotti apud (VAZ, Laurita, III Simpósio de Direito Previdenciário da Escola Paulista de Direito Social).

Em outros julgados esse Tribunal sempre defendendo a possibilidade de renúncia à aposentadoria já afirmou que, seja no mesmo regime, ou em regimes distintos, não deve haver a devolução de valores pelo segurado, justificando tal posição primeiramente no caráter alimentar que possuem tais benefícios, pois visam à substituição da renda do trabalhador e também no fato do segurado que retornou ao trabalho continuar contribuindo sem qualquer contrapartida. Além do mais, se a renúncia ocorrer em um regime visando o ingresso em outro não há óbice de que se dê sem 
Id on Line Revista Multidisciplinar e de Psicoloqia

Id on Line Revista Multidisciplinar e de Psicologia

devolução de parcelas, pois a Lei 9.796/99 determina a compensação financeira de um regime para o outro. Neste sentido temos o Resp. 557.231/RS.

Além do mais, o STJ já confirmou a tese da desaposentação em julgamento de recurso repetitivo (Resp. 1334488/SC de Relatoria do Ministro Herman Benjamin), que ocorre quando um Tribunal Superior constatando que existem sucessivos recursos tratando da mesma matéria instaura um incidente para a fixação da tese jurídica a ser aplicada em todas as causas repetitivas. Suspende-se, então, o processamento de todos os recursos repetidos em instâncias inferiores sobre aquele assunto, ficando a espera da decisão modelo que vinculará a todos. Foi o que aconteceu quando do julgamento deste recurso. Isso significa que esta decisão do STJ serve de modelo para todos os TRF's do país que terão que se adequar ao entendimento do STJ. Ou seja, recursos com pedidos iguais que tramitem nesses Tribunais devem ser julgados conforme decisão proferida nesse recurso repetitivo. Deste modo, no STJ a tese da desaposentação é pacífica.

\section{Posicionamento Do STF}

Ao converter a Medida Provisória $n^{\circ}$ 676/2015 na Lei $n^{\circ}$ 13.183/2015 a presidente Dilma Rousseff vetou dispositivo que admitiria a desaposentação no Ordenamento Jurídico brasileiro, sendo tal veto mantido pelo plenário do Congresso Nacional. Assim, o futuro da desaposentação encontra-se nas mãos do STF (Supremo Tribunal Federal) que é o órgão de cúpula do Poder Judiciário brasileiro, tendo como função, precipuamente, a guarda da Constituição Federal, conforme art. 102 da CF/88.

Neste momento tramitam no STF dois Recursos Extraordinários que deverão ser julgados muito em breve. No RE 381.367 aposentadas do Rio Grande do Sul que retornaram ao trabalho buscam o direito de ter suas aposentadorias recalculadas pelo INSS, pois voltaram a contribuir para a Previdência, o que atualmente não tem previsão legal. Alegam a inconstitucionalidade do $\S 2^{\circ}$ do art. 18 da lei 8.213/91 por contrariar disposição contida no § 11 do art. 201 da CF/88 que determina que "os ganhos habituais do empregado, a qualquer título, serão incorporados ao salário para efeito de contribuição previdenciária e consequente repercussão em benefícios, nos casos e na forma da lei”. O julgamento deste recurso já foi iniciado no STF, sendo que o relator Ministro Marco Aurélio votou favoravelmente à desaposentação:

Em síntese, ao trabalhador que, aposentado, retorna à atividade cabe o ônus alusivo à contribuição, devendo-se a ele a contrapartida, os benefícios próprios, mais precisamente a consideração das novas contribuições para, voltando ao ócio com dignidade, calcular-se, ante o retorno e as novas contribuições e presentes os requisitos legais, o valor a que tem jus sob o ângulo da aposentadoria. Essa conclusão não resulta na necessidade de declarar-se inconstitucional o $\$ 2^{\circ}$ do artigo 18 da Lei $\mathrm{n}^{\circ}$ 8.213/91, mas em emprestar-lhe alcance consentâneo com a Carta 
Id on Line Revista Multidisciplinar e de Psicoloqia

Id on Line Revista Multidisciplinar e de Psicologia

Federal, ou seja, no sentido de afastar a duplicidade de benefício mas não o novo cálculo de parcela previdenciária que deva ser satisfeita. É como voto na espécie".

O julgamento deste recurso foi retomado em outubro de 2014, na ocasião os ministros Dias Toffoli e Teori Zavascki votaram contra a desaposentação, argumentando que o $\S 2^{\circ}$, artigo 18, da Lei 8.213/91 é constitucional, porém, neste momento, o processo encontra-se suspenso, tendo em vista que a Ministra Rosa Weber pediu vistas dos autos, ficando o deslinde da questão sem prazo determinado.

O outro recurso pendente é o RE 661.256 que foi interposto pelo INSS contestando uma decisão do STJ que concedeu a um segurado o direito a renunciar a sua aposentadoria com o objetivo de obter benefício mais vantajoso no futuro, sem necessidade de devolução de valores recebidos da previdência quando da aposentadoria. O INSS alega violação ao ato jurídico perfeito, art. $5^{\circ}$, Inciso XXXVI da CF e ao equilíbrio atuarial do sistema, arts.195, caput e $\S 5^{\circ}$ e 201, caput da CF/88. O STF reconheceu Repercussão Geral na matéria, por causa da relevância política, econômica e social, ou seja, essa decisão servirá de base para milhares de processos idênticos pendentes no Brasil sobre desaposentação. O relator do processo, Ministro Luís Roberto Barroso, no mês de outubro de 2014 votou no sentido de considerar válido o instituto:

Inexistem fundamentos legais válidos que impeçam à renúncia a aposentadoria concedida pelo Regime Geral da Previdência Social para o fim de requerer um novo benefício, mais vantajoso, tendo em conta contribuições obrigatórias efetuadas em razão de atividade de trabalho realizada após o primeiro vínculo. Tem que haver uma correspondência mínima entre contribuição e benefício, sob pena de se anular o caráter contributivo do sistema. O legislador não pode estabelecer contribuição vinculada e não oferecer qualquer benefício em troca.

Logo após o voto do relator o processo foi suspenso, pois estavam ausentes justificadamente três Ministros, devendo ser apreciado em breve pelo Plenário completo do Tribunal.

Assim, a questão encontra-se empatada no STF, tendo dois votos a favor dos Ministros Luís Roberto Barroso e Marco Aurélio e dois contra dos Ministros Dias Toffoli e Teori Zavascki.

A decisão final sobre a admissibilidade da tese da desaposentação no Brasil será dada pelo STF quando da conclusão do julgamento desses recursos pendentes que deverão ser julgados em conjunto. A não ser que o STF decida pela inconstitucionalidade da desaposentação a posição a ser seguida hoje é no sentido de ser possível a renúncia à aposentadoria, sem devolução de valores, conforme decisão em recurso repetitivo do STJ sobre o tema.

\section{Conclusão}

Diversos segurados brasileiros que retornaram ou continuaram a trabalhar vinculados ao RGPS encontram diante de si um problema, pois a legislação previdenciária vigente não lhes permite 
Id on Line Revista Multidisciplinar e de Psicologia

Id on Line Revista Multidisciplinar e de Psicologia

renunciar a sua atual aposentadoria visando à utilização do tempo de contribuição excedente para o recálculo de um novo benefício mais vantajoso. Administrativamente, então, a autarquia gestora dos benefícios do RGPS (INSS) vem negando os pedidos, o que leva muitos segurados a procurarem o Judiciário objetivando a solução da questão, o que tem gerado decisões divergentes e conflitantes entre si.

Assim, há alguns anos, doutrina e a jurisprudência pátria vêm se digladiando sobre a admissibilidade do instituto da desaposentação no Brasil. Esta pesquisa teve como principal objetivo a demonstração da viabilidade da tese da desaposentação no Ordenamento Jurídico Constitucional brasileiro através da desconstituição dos principais argumentos contrários, quais sejam, desequilíbrio financeiro e atuarial do sistema, o ato jurídico perfeito, a falta de previsão legal e o art. $18, \S 2^{\circ}$ da Lei $8.213 / 91$.

Quanto ao art. $18, \S 2^{\circ}$ da Lei 8.213/91 que determina que os segurados aposentados que continuarem em serviço ou retornarem não farão jus à prestação alguma da previdência social em decorrência do exercício dessa atividade, esclarecemos que o mesmo não é óbice a desaposentação, tendo em vista a sua flagrante inconstitucionalidade por afronta ao § 11 do art. 201 da CF/88. Questão que está sendo apreciada pelo STF no julgamento do RE 381.367.

Evidenciamos também a possibilidade de desfazimento do ato jurídico perfeito de concessão da aposentadoria, considerando que as garantias constitucionais foram desenvolvidas para a defesa do cidadão, que neste caso é o segurado, contra a ingerência do Estado e não para perenizar injustiças. Portanto, o ato jurídico perfeito de concessão da aposentadoria impede o desfazimento da mesma pela administração pública, mas não impede a renúncia pelo segurado, visto que é um direito patrimonial seu logo, disponível. Deste modo, tentar impedir a desaposentação utilizando um direito feito para o povo contra ele mesmo é lesar a própria Constituição Federal.

Demonstramos ainda que a desaposentação é plenamente viável do ponto de vista atuarial, pois os segurados que permanecem ou retornam ao labor não oneram o sistema como dizem alguns, ao contrário, suas novas contribuições constituem um adicional, uma receita não esperada. Sendo plenamente cabível a renúncia a atual aposentadoria objetivando o recálculo das mesmas com base nessas novas cotizações. Não havendo, por conseguinte, a necessidade de devolução dos valores percebidos pelos segurados durante o período em que estiveram aposentados.

Por fim, desconstituímos o argumento muito utilizado pelo INSS para negar o direito à renúncia aposentadoria, a falta de previsão legal. Esta não constitui impedimento a desaposentação, haja vista que se faz necessário atribuir ao princípio da legalidade sua amplitude correta, ou seja, a administração somente pode impor ao segurado as restrições previstas em lei. Destarte, como a desaposentação não está proibida em lei, presume-se que é permitida. Ademais, vislumbramos uma clara colisão entre princípios constitucionais, de um lado temos o Princípio da Liberdade do segurado e de outro o Princípio da Supremacia do Interesse Público. Ponderando este conflito concluímos pela 
Id on Line Revista Multidisciplinar e de Psicoloqia

Id on Line Revista Multidisciplinar e de Psicologia

prevalência do Princípio da Liberdade, pois os direitos e garantias individuais previstos na Constituição são muito mais relevantes do que a Supremacia do Interesse Público.

Diante da omissão legislativa sobre a questão e com o fim do pecúlio, desaposentar se mostra a melhor opção para fazer justiça social aos milhares de segurados que continuam ou retornam ao labor. Não se pode admitir em um Estado que possui uma Constituição como a nossa tão preocupada em resguardar direitos para os seus trabalhadores que o segurado seja prejudicado em relação ao melhoramento de sua aposentadoria, tendo em vista que esta visa à manutenção do seu padrão de vida na época em que mais precisa, pois a idade avançada geralmente traz maiores necessidades.

Assim sendo, confirmamos que a tese da desaposentação se mostra plenamente viável e válida no Ordenamento Jurídico brasileiro, encontrando fundamento na própria Constituição Federal, uma vez que resguarda direito individual do segurado, além de princípios como o da liberdade, da contrapartida e da dignidade da pessoa humana.

\section{Referências}

BANDEIRA DE MELlO, Celso Antônio. Curso de Direito Administrativo. 29a ed. São Paulo: Malheiros, 2012.

BRAMANTE, Ivani Contini. Desaposentação e nova aposentadoria. Rio de Janeiro. Revista RDA, a XXV, n.144, mar./01.

BRASIL. Constituição da República Federativa do Brasil de 05 de outubro de1988.Disponívelem: $<$ http://www.planalto.gov.br/ccivil_03/constituicao/ConstituicaoCompilado.ht m> Acesso em:20/02/2016.

BRASIL. Decreto no 3.048 de 06 de maio de 1999. Aprova o Regulamento da Previdência Social e dá outras providências. Disponível em <http://www.planalto.gov.br/ccivil 03/decreto/d3048.htm>. Acesso em: 15/03/2016.

BRASIL. Lei no 8.213 de 24 de julho de 1991. Dispõe sobre os Planos de Benefícios da Previdência Social e dá outras providências. Disponível em: <http://www.planalto.gov.br/ccivil_03/leis/L8213cons.htm> Acesso em 24/01/2016.

BRASIL. Lei $\mathbf{n}^{\mathbf{0}} 8.212$ de 24 de julho de 1991. Dispõe sobre a organização da Seguridade Social, institui Plano de Custeio, e dá outras providências. < http://www.planalto.gov.br/ccivil_03/leis/L8212cons.htm> Acesso em: 21/01/2016.

BRASIL. Lei $\mathbf{n}^{\circ} 8112$ de 11 de dezembro de 1990. Dispõe sobre o regime jurídico dos servidores públicos civis da União, das autarquias e das fundações públicas federais. Disponível em: <http://www.planalto.gov.br/CCIVIL_03/leis/L8112cons.htm>. Acesso em: 07/03/2016.

BRASIL. Lei 8.870 de 15 de abril de 1994. Altera dispositivos das Leis $n^{\circ}$ s 8.212 e 8.213, de 24 de julho de 1991, e dá outras providências. Disponível em: http://www.planalto.gov.br/ccivil 03/leis/L8870.htm. Acesso em: 05/02/2016. 
Id on Line Revista Multidisciplinar e de Psicoloqia

Id on Line Revista Multidisciplinar e de Psicologia

BRASIL. Superior Tribunal de Justiça. REsp 692.628/DF. Relator Ministro Nilson Naves. Data de julgamento: 17.05.2005. 6.Turma. Data da Publicação: 05/09/2005. Disponível em: <http://www.stj.jus.br>. Acesso em 09/02/2016.

BRASIL. Superior Tribunal de Justiça. REsp 557.231/RS. Relator Paulo Gallotti. Data de Julgamento: 08/04/2008. 6.Turma. Data de julgamento: 08/04/2008. Disponível em: <http://www.stj.jus.br>. Acesso em 12/02/2016.

BRASIL. Supremo Tribunal Federal. RE 381.367/RS. Relator. Marco Aurélio. Pendente de julgamento. Disponível em: 〈http://www.stf.jus.br〉. Acesso em:15/02/2016.

BRASIL. Superior Tribunal de Justiça. Resp1334488/SC. Relator Ministro Herman Benjamin. Data de Julgamento: 08/05/2013. S1 Primeira Seção. Data da Publicação: 14/05/2013. Disponível em: < http://www.stj.jus.br> Acesso em 12/02/2016.

BRASIL. Supremo Tribunal Federal. RE 661.256 DF. Relator Ministro Roberto Barroso. Pendente de julgamento. Disponível em: <http://www.stf.jus.br> Acesso em 05/02/2016.

COELHO, Hamilton Antônio. Desaposentação: “Um novo instituto?" Revista do Tribunal de Contas do Estado de Minas Gerais, edição $n^{\circ} 01$ de 2000- Ano XVIII. Disponível em <http://200.236.18.67:8080/tribunal_contas/2000/01/-sumario? next=5. Acesso em 28/03/2016.

DUARTE, Marina Vasquez. Temas Atuais de Direito Previdenciário e Assistência Social. Porto Alegre: Livraria do Advogado Editora, 2003. Apud Társis Nametala Jorge. Disponível em: http://www.fdc.br/artigos/direito adquirido.htm. Acesso em: 25/03/2016.

IBRAHIM, Fábio Zambitte. Curso de Direito Previdenciário. 13. ed. Rio de Janeiro: Impetus, 2008.

IBRAHIM, Fábio Zambitte. Desaposentação o caminho para uma melhor aposentadoria. 5.ed.Rio de Janeiro: Impetus, 2011.

KRAVCHYCHYN, Gisele Lemos. Desaposentação. Fundamentos jurídicos, posição dos tribunais e análise das propostas legislativas. Jus Navigandi, Teresina, ano 12, n. 1622, 10 dez. 2007. Disponível em: <http://jus2.uol.com.br/doutrina/texto.asp?id=10741>. Acesso em: 22/01/2016.

LADENTHIN, Adriane Bramante de Castro; MASOTTI Viviane. Desaposentação Teoria e Prática. Curitiba: Juruá Editora, 2012.

LEITÃO, André Stuart. Aposentadoria Especial. Doutrina e Jurisprudência. $1^{\text {a }}$ ed. São Paulo: Quartier Latin, 2007.

LINDOSO, Alexandre Simões. $\mathbf{O}$ aposentado que permanece ou retorna à atividade remunerada e a inconstitucionalidade do artigo $18, \quad \S \mathbf{2}^{\circ}$ da Lei $\mathbf{n}^{\circ}$ 8.213/91. Disponível em:http://www.ambitojuridico.com.br/site/index.php?n_link=revista_artigos_leitura\&artigo_id=4815. Acesso em 23/01/2016.

MARTINEZ, Wladimir Novaes. Curso de Direito Previdenciário. 3.ed. São Paulo: Ltr, 2010.

MARTINEZ, Wladimir Novaes Desaposentação. LTr: São Paulo, 2008, p.111.

NOVELINO, Marcelo. CUNHA JR, Dirley da. Constituição Federal para concursos. 3. Ed. Bahia: JusPodivm. 2012. 
SALVADOR, Sérgio Henrique; AGOSTINHO, Theodoro Vicente. Desaposentação - Instrumento de proteção previdenciária. São Paulo: Conceito Editorial, 2011.

TAVARES, Marcelo Leonardo. Direito Previdenciário. 6a ed. Rio de Janeiro: Lumen Juris, 2005.

VIANNA, João Ernesto Aragonés. Curso de Direito Previdenciário. 4. ed. São Paulo: Atlas, 2011.

\section{Como citar este artigo (Formato ABNT):}

GINO, B.S.B.D.; SILVA, E.S.S.F.; DANTAS, T.C.C.P. A Desaposentação no Ordenamento Jurídico Brasileiro. Id on Line Revista Multidisciplinar e de Psicologia, Julho de 2016, vol.10, n.30. p. 130148. ISSN 1981-1179.

Recebido: 01/07/2016

Aceito:04/07/2016 